Balasubramanian, S. C. \& Ramachandran, M. (1952). J. gen. Microbiol. 7, 44-47

\title{
On the Microbiological Assay of Threonine
}

\author{
By S. C. BALASUBRAMANIAN AND M. RAMACHANDRAN \\ Nutrition Research Unit, Department of Biochemistry, Indian Institute \\ of Science, Bangalore, India
}

SUMMARY: A small lag section has been noticed in the standard curves obtained in the estimation of threonine using Streptococcus faecalis $R$. An increase in the acetate and phosphate buffers in the basal medium has been found to be advantageous.

While investigating the amino-acid composition of some Indian foods by the microbiological method, the authors made certain observations concerning the assay of threonine with Streptococcus faecalis $R$ to which little attention has been paid in the literature. Barton-Wright (1946), Horn, Jones \& Blum (1947) and several other workers have employed Strep. faecalis $R$ for the assay of this amino-acid.

An initial lag section was observed in the standard threonine curves when Strep. faecalis $R$ was used as the test organism. Certain minor improvements to the basal medium have also been made to secure a good response over a wide range of the amino-acid.

\section{EXPERIMENTAL}

Strep. faecalis $R$ (ATCC 9790) was used throughout these studies.

The basal media and the method of Barton-Wright (1946), with certain minor modifications, have been successfully employed in this laboratory for the routine assay of the various amino-acids in foods. The final volume was $5 \mathrm{ml}$./tube, made up of $2.5 \mathrm{ml}$. basal medium and $2.5 \mathrm{ml}$. standard solution and water. This reduction in volume was mainly effected so as to economize the use of the costly synthetic amino-acids. Xanthine was not available and hence was omitted from the media. The concentration of amino-acids and other ingredients in the media was the same as recommended by BartonWright (1946).

When threonine was determined by the above method, the acid production was rather low and the range of the standard curve was also limited $(6 \mathrm{ml}$. $0.025 \mathrm{~N}$ acid for a range of $0-20 \mu \mathrm{g}$. of DI-threonine) even after making due allowances for the reduced final volume/tube. An increase in the concentration of glucose and sodium acetate alone had been found to be without effect on the acid production (Barton-Wright, 1946).

A survey of the literature revealed that sodium citrate had a high buffering action and allowed better growth and acid-production than sodium acetate for Strep. faecalis (Teply \& Elvehjem, 1945; Rabinowitz \& Snell, 1947). Hence, the search for a medium which contained sodium citrate as a buffer resulted in the media and the method of Sauberlich \& Baumann (1946). A trial was made with this method. However, it was found that this method also suffered from several disadvantages. The end-point with bromothymol blue in the final 
titrations of the acid produced was not sharp, the colour change being imperceptibly slow even after the addition of an excess of $0.5-1 \cdot 0 \mathrm{ml}$. alkali. Moreover, the acid production was also low. $(5 \mathrm{ml} .0 .025 \mathrm{~N}$ acid for a range of 0-20 $\mu \mathrm{g}$. of DL-threonine). When sodium citrate was replaced by sodium acetate in the medium, the end-points were sharp, but the acid production and range of the curve continued to be as before. Further, when the medium with sodium acetate was used to assay the threonine content of foods, erratic values were obtained. There was no agreement among the values calculated at different assay levels, the standard curves were not superimposable, and the values were not reproducible.

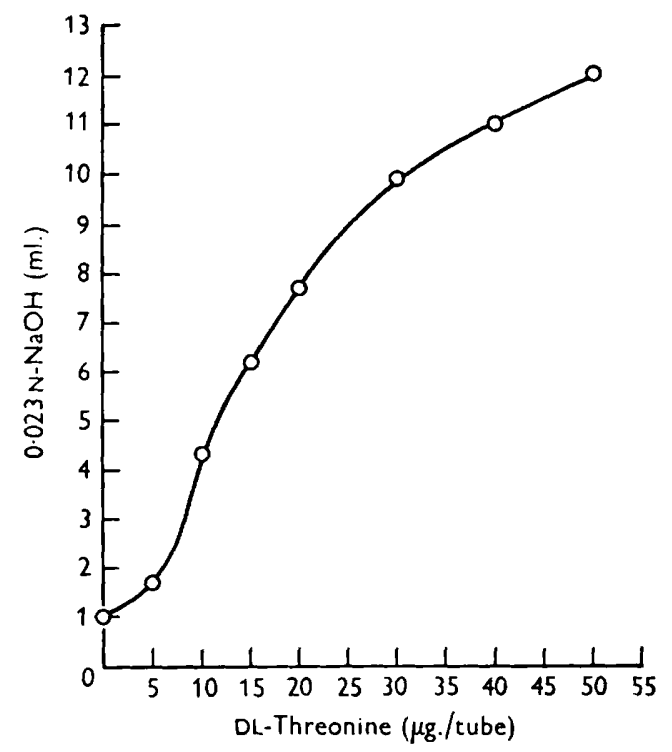

Fig. 1. A typical standard curve obtained in the assay of threonine employing Strep. faecalis $\boldsymbol{R}$.

An attempt was therefore made to use the original method of Barton-Wright (1946) itself, with certain additional modifications. The buffering capacity of the medium was increased by doubling the concentration of sodium acetate and of the phosphates. The amount of glucose was also doubled, since in the presence of increased buffers greater acid production might be possible with more glucose. Satisfactory end-points and good acid production were obtained. ( $11 \mathrm{ml} .0 .025 \mathrm{~N}$ acid for a range of $0-50 \mu \mathrm{g}$. of DL-threonine.) Values obtained by the use of this modified medium on foods were reliable on the basis of the various criteria for dependability of microbiological assays.

A typical standard curve obtained in the assay of threonine with the modified medium is shown in Fig. 1. 


\section{DISCUSSION}

It may be seen from the standard curve that there is an initial lag section in the region $0-5 \mu \mathrm{g}$. DI-threonine and that maximum acid production occurs at $50 \mu \mathrm{g}$. of the DL-acid, after which the curve becomes parallel to the abscissa. Horn et al. (1947) have reported a response up to $200 \mu \mathrm{g}$. DL-threonine, with $10 \mathrm{ml}$. as the final volume/tube. However, though the same organism from the same source was used in the present case, the response and the range were not as high as could be expected, even after making due allowance for the restricted final volume employed.

Meinke \& Holland (1948), while studying the inhibition of serine utilization by threonine in some lactic acid bacteria, made an incidental observation that there was also an inhibition of threonine utilization by serine. Although no detailed figures were given, they concluded that a ratio of scrine to threonine of less than 200:1 for Strep. faecalis $R$ was necessary for the successful utilization of threonine in presence of serine. This may possibly explain some of our observations. In the present modified medium, DL-serine is present to the extent of $1 \mathrm{mg}$./tube. Hence, it can be expected that when Strep. faecalis $\boldsymbol{R}$ is used as the organism, $1 \mathrm{mg}$. $/ 200$, i.e. at least $5 \mu \mathrm{g}$. threonine, must be present to circumvent the inhibitory effect of serine. The lag section in the standard threonine curves of the authors can, therefore, be attributed to some extent to the presence of serine in the medium at the level indicated.

In the case of the workers who developed curves up to $200 \mu \mathrm{g}$. threonine, it is possible that this small lag section was overlooked.

The implications of this lag section on the interpretation of the curve are quite obvious. In addition to the serine present in the medium, a small amount of serine is likely to be provided by the experimental hydrolysates. A measure by which the effect of added serine can be made insignificant is to have a sufficiently large amount of serine in the medium itself. The present modified medium satisfies such a condition since the amount of serine from the medium will be $1 \mathrm{mg}$./tube and any serine contributed by the hydrolysates may be only of the order of $50 \mu \mathrm{g}$.- - a variation of only $5 \%$ in the total serine content.

The levels of hydrolysate should be conveniently chosen so that readings are obtained between 10 and $40 \mu \mathrm{g}$. DL-threonine and the lag section of the curve is avoided. Such a procedure has been found to give highly reliable and reproducible values.

The values for the threonine content of some Indian foods using the modified medium will be reported elsewhere in due course.

The authors are indebted to Dr S. S. De for valuable advice and helpful criticism, to Dr K. V. Giri for his keen interest, to Dr M. Sirsi for kind help in maintenance of cultures and to the Indian Council of Medical Research for generous financial assistance. 


\section{REFERENCES}

Barton-Wright, E. C. (1946). The microbiological assay of amino-acids. I. The assay of tryptophan, leucine, isoleucine, valine, cystine, methionine, lysine, phenylalanine, histidine, arginine and threonine. Analyst, 71, 267.

HonN, M. J., Jones, D. B. \& Buum, A. E. (1947). Microbiological determination of threonine in proteins and foods. J. biol. Chem. 169, 739.

Meinke, W. W. \& Holland, B. R. (1948). Threonine-serine antagonism in some lactic acid bacteria. J. biol. Chem. 173, 535.

Rabinowitz, J. C. \& Snell, E. E. (1947). The vitamin $B_{6}$ group. XI. An improved method for assay of vitamin $\mathrm{B}_{6}$ with Streptococcus faecalis. J. biol. Chem. 169, 631.

Sauberlich, H. E. \& Batmann, C. A. (1946). The effect of dietary protein upon amino-acid excretion by rats and mice. J. biol. Chem. 166, 417.

Teply, L. J. \& ElvehJem, C. A. (1945). The titrimetric determination of 'Lactobacillus casei factor' and 'folic acid'. J. biol. Chem. 157, 303.

(Received 1 January 1952) 